\title{
LEARNING MANAGEMENT IN IMPROVING THE QUALITY OF GRADUATES MADRASAH DINIYAH TAKMILIYAH AWALIYAH (MDTA) IN SUKABUMI DISTRICT
}

\author{
Usman Armaludin \\ STAI Al Andina Sukabumi \\ Email: armaludinusman@gmail.com \\ lim Wasliman \\ Nusantara Islamic University \\ Email: iim_wasliman@yahoo.com \\ Deti Rostini \\ Nusantara Islamic University \\ Email: detirostini@uninus.ac.id
}

\begin{abstract}
This research is motivated by the existence of an interesting phenomenon in the implementation of Madrasah Diniyah Takmiliyah Awaliyah (MDTA) in Sukabumi Regency. The regional government's very strong attention to religious education in Sukabumi District, the lack of conditions for MDTA infrastructure, inadequate learning management at MDTA, limited sources of activity funds, and the structure of the MDTA curriculum that has not been fully understood have become the focus of problems in this research. This study presents the results of research on Learning Management in Improving the Quality of Madrasah Diniyah Takmiliyah Awaliyah Graduates in Sukabumi District. . This study is a qualitative research with descriptive methods were performed on MDTA in three (3) the District, the District, Cicantaya $\mathrm{n}$, Caringin and Cisaat. The data collection technique combines field observations, in-depth interviews and documentation studies. Inductive data analysis resulted in the following conclusions: in general, the management of Learning in Improving the Quality of Madrasah Diniyah Takmiliyah Awaliyah Graduates (MDTA) in Cicantayan, Caringin and Cisaat Districts, Sukabumi Regency has not run optimally. In particular, first, the policy product of the Sukabumi Regency Government in the provision of education at MDTA has been successfully implemented even though the realization of the operational assistance budget and the pattern of guidance and supervision are still not optimal. Second, the achievements of the results of the implementation of learning at MDTA so far have been sufficient to meet the graduation standards of students, but in the implementation of learning activities still do not meet the standards of the learning process. Third, there are some inhibiting factors faced in the form of limited budget, weak understanding of the methodology and the mindset of teachers in learning, inadequate learning facilities, and the absence of a national madrasah diniyah curriculum standard. Fourth, the future demands are in the form of community support for the development of MDTA with a modern and innovative perspective, the formation of the diniyah teachers' deliberation forums and the professional training of teachers. Fifth, several improvements have been made in the form of holding MDTA accreditation and strengthening the Diniyah Takmiliyah Communication Forum (FKDT). And the sixth is the impact obtained from the implementation of education at MDTA in the form of a religious community environment, holding back the moral decadence of the younger generation and creating religious figures in the Cicantayan, Caringin and Cisaat Districts. This study also offers a hypothetical model for the application of learning management to MDTA..
\end{abstract}

Keywords: Learning Management; Madrasah Diniyah Takmiliyah Awaliyah; Quality of Graduates 


\section{A. INTRODUCTION}

The government has given space in order to improve the quality of Madrasah Diniyah through U ndang Law No mor 20 of 2003 on National Education System, then followed up with P eraturan P he Government of Number 55 Year 2007 regarding Religious Education and Religious Education which states that the Madrasah Diniyah as one the form of Islamic religious education can be carried out in formal, non-formal, and informal channels. However, this policy is still difficult to implement because it still requires further operational rules to elaborate the Government Regulation. In the period 2007 to the present the Minister of Religion Regulation (PMA) which regulates Madrasah Diniyah was only issued in 2014, in the form of PMA Number 13 of 2014 concerning Islamic Religious Education. If measured by the issuance of the National Education System Law Number 20 of 2003 to 2014, a new Minister of Religion Regulation has emerged which regulates Madrasah Diniyah. This shows that the policies towards religious education institutions are very slow.

However, the attention of the local government of Sukabumi Regency in improving religious education and the development of Islamic religious education is very strong. This is evidenced by the issuance of Regional Regulation Number 8 of 2009 concerning compulsory Islamic Religious Education and followed up by Sukabumi Regent Regulation Number 13 of 2018 concerning Minimum Service Standards for Non-formal Diniyah Education at the Awaliyah Level as well as in improving the service and development of Madrasah Diniyah Awaliyah, the Sukabumi Regent also issued Sukabumi Regent Regulation Number 14 of 2018 concerning Nonformal Diniyah accreditation and is followed up by Regent Regulation Number 14 of 2018 with Regent Sukabumi Decree Number 451.05 / Kep.255.SK / 2018 concerning the Compulsory Education Coordination Team for Islamic Religious Education. Then amplified by the decision of the Head Office of the Ministry of Religious Sukabumi 6283 No. 2018 on Minimum Service Standards Diniyah Non-formal Education Level Keme Awaliyah Office $n$ ministries Religion Sukabumi .

The fact the field of the study results preliminary through field observations at Madrasah Diniyah Takmiliyah Awwaliyah (MDTA) in the territory of the District Caringin there are 54 institutions MDTA, with the number of teachers 130 people from 54 institutions sub-district Caringin floo a i the number of pupils or students of Madrasah Diniyah Takhmiliyah Awaliyah numbered 4349 while in Cicantayan District, there are 63 institutions out of which 212 have teachers or ustadz and ustadzah while the number of students or students at Madrasah Diniyah Awaliyah in Cicantayan District is 5266 people while in Cisaat sub-district there are 75 MDTA institutions and 251 teachers while the number of students or 6929 students.

Problems arising from the results of the preliminary study of madrasah diniyah in the three sub-districts include: 1) funding problems which generally only come from the founders or owners of the foundation; 2) problems with personnel or teachers, who on average are modestly obtained so that they do not have mastery of the material being taught; 3) facilities and facilities; and 4) very limited allocation of learning time. All of these problems are of course very influential on the continuity of the learning process at Madrasah Diniyah Takmiliyah Awaliyah which ultimately leads to inaccurate or inadequate learning outcomes and has an impact on the overall quality of Dinyah Takmiliyah Awaliyah Madrasah graduates.

Based on the identification of the above problems, the formulation of research problems on How Learning Management in Improving the Quality of Madrasah Diniyah Takmiliyah Awaliyah (MDTA) Graduates in Sukabumi District . so that the authors feel interested in exploring in depth about: 1) How is the Sukabumi Regency Government Policy in the implementation of learning management ? 2) How is the achievement of learning management in improving the quality of MDTA graduates ? 3) What are the inhibiting factors in the application of learning management in improving the quality of MDTA graduates ; 4) What are the benefits and expectations of the application of learning management in improving the quality of MDTA graduates ; 5) What is the solution and efforts to improve in the future learning management in improving the quality of MDTA graduates ; and 6 ) How does the activity impact the religious life of MDTA students? 
Based on the research results that have been conducted before, the researchers did not find the same research focus. however the researchers found several studies that had been conducted that were similar to what the researcher was about to research. First, research conducted by Juju Saepudin (2019) in the Journal of the SMaRT Study of Society, Religion and Tradition. Who Researches About the Integration of Learning Madrasah Diniyah Takmiliyah to Schools (Case Study at Cisaat State Elementary School, Sukabumi Regency). Which resulted in several conclusions, namely first, the integration of MDT learning at SDN Cisaat was carried out through an integrative and collaborative model. Second, the MDT learning integration model at SDN Cisaat is new in the form of curriculum content and the empowerment of some MDT teachers, not yet in the form of learning places or facilities. Third, the motivation of the MDT managers, the enthusiasm of the Diniyah Takmilyah Communication Forum (FKDT) board, and the existence of Regional Regulations (Perda) and Regent Regulations (Perbup) are all supporting factors for the integration of learning. Meanwhile, the limited facilities and infrastructure and the absence of a special MDT supervisor have an effect on the implementation of learning at MDT to be less professional .

Furthermore, the results of Winda, Rido Kurnianto, Ayok Ariyanto (2018) in the TARBAWI Journal journal, which examined the Learning Management at Madrasah Diniyah Nurul Huda Krajan Krebet Jambon Ponorogo. The results of this study found that the procedures carried out were preceded by planning, organizing, implementing, monitoring and evaluating. Specifically: (1) Empowerment planning using a participatory system. (2) Organizing with the division of labor tasks. (3) Implementation begins with recruitment, coaching, training and education, coaching, apprenticeship and follow-up. Constraints include inadequate infrastructure, inadequate teachers, low community support capacity, low student motivation. To overcome this, the school and community empowerment steps were taken. (4) control which includes monitoring, assessment and evaluation is carried out by means of written, oral or practical tests.

While the theory underlying this research is: 1 ) Theory of Management. Terry in Kompri (2018: 2-3) defines management as follows:

Management is a distinct process consisting of planing, organizing, actuating, and controlling performed to determine and accomplish stated objectives by the use human being and other resources .

2) Learning Theory . According to Gagne in Wandini (2018: 2), learning can be defined as a process in which an organism changes its behavior as a result of experience and teaching are two concepts that cannot be separated from one another. These two concepts become integrated in one activity where there is interaction between the teacher and students, as well as students and students during the learning process. 3) Quality theory. According to Juran in Zamroji (2020: 10), product quality is the suitability of product use (fitness for use) to meet customer needs and satisfaction. The suitability of the users of the product is based on five main characteristics, namely (1) technology; namely strength; (2) psychological, namely taste or status; (3) time, namely reliability; (4) contractual, namely there is a guarantee; (5) ethics, namely courtesy

\section{B. METHOD}

This research uses a qualitative approach with descriptive methods, makes a systematic, factual and accurate description of the phenomena or the relationship between the phenomena being studied.

The basic principle of using the qualitative descriptive method is based on the opinion of Bogdan and Biklen in Hidarya et al. ( 2020 : 229 ): " Qualitative research is descriptive". Moleong (2007: 11) emphasizes that in descriptive qualitative research the data collected is in the form of words, pictures, and not numbers. Questions with the word wonder why, what reason and how it happened will always be used by researchers Moleong (2007: 11 ) emphasizes that the research kualiatatif descriptive of data were collected in the form of words, pictures, and not numbers. Then according to Creswell (2016: 4): "Qualitative research is methods to explore and understand the meaning - a number of individuals or groups that are considered to come from social or human problems" 
Data mining was carried out through observation, interviews, photoshoots, written snippets from documents at the research location which were arranged in a narrative manner, through the preparation, implementation and data collection stages. Data collection and observation activities were carried out at MDTA, Cicantayan, Caringin and Cisaat Districts, Sukabumi Regency in the period of June to December 2020. Meanwhile, the research subjects were: 1) MDTA teachers ; 2) Head of MDTA ; 3) Head of Section for PD Pontren Ministry of Religion of Sukabumi Regency; 4) Head of Social and Religious Affairs for Sukabumi Regency: 5) Community ; Furthermore, data analysis was carried out in the form of a series of data management activities from the beginning and throughout the research process. As stated by Bogdan and Biklen in Moleong (2007 : 248 ) that: Qualitative Data Analysis is an effort made by working with data, organizing data, sorting it into manageable units, synthesizing it, looking for and finding patterns, finding what is important and what is learned, and deciding what to share with other people.

In this study, data analysis was used according to the interactive model of the Data Analysis Components of Miles and Huberman, in Hidarya et al. (2020: 230) that qualitative data analysis is carried out interactively and takes place continuously (until the data is saturated) which includes: (1) data reduction; (2) display data ; and (3) conclusion: drawing / verifying (drawing conclusions and verification).

\section{RESULTS AND DISCUSSION}

\section{Sukabumi District Government Policy}

Carl Fredrich in Wahab (2004: 3) explains that the policy is s ne action that leads to the goal proposed by a person, group or government particular environment in connection with certain constraints while seeking an opportunity - an opportunity to achieve the goals or realize the desired goals. In this case the policy strategy issued by the Regent through Number 8 of 2009 concerning compulsory Islamic Religious Education and followed up by the Sukabumi Regent Regulation Number 13 of 2018 concerning Minimum Service Standards for Early Level Non-formal Early Education is an initiative of the Regent and Legislative in an effort to solve the problems faced in providing quality education at Madrasah Diniyah Takmiliyah. This policy is the right strategy to solve the problems faced by Madrasah Diniyah Takmiliyah administrators in improving its quality .

The objectives of quality education policies and programs at Madrasah Diniyah Takmiliyah Awaliyah in Sukabumi District are: 1) to create a society with noble character, advancing towards a prosperous Sukabumi Regency through the quality MDTA education program ; 2) Require that every citizen who is going to formal school must have a diploma / certificate ; 3) Placing Madrasah Diniyah as part of the compulsory basic education program ; 4) Determining Standard Madrasah Diniyah curriculum. 5) Preparing Madrasah Diniyah Accreditation Guidelines .

Through a policy strategy like this, the Sukabumi District Government has taken other strategic steps, including the issuance of certificates for students who have graduated from MDTA. This is as regulated in Regional Regulation Number 8 of 2009 Article 5 paragraph (1) to paragraph (5) as follows: 1) Students who have met the competency standards of Islamic religious education are given a diploma or graduation certificate. 2) A diploma or certificate of graduation from Islamic religious education is one of the requirements to continue at the formal further education level. 3) For students who do not have a diploma or certificate of graduation, the education unit is obliged to organize a special program

\section{Learning Management Achievements in Improving the Quality of MDTA Graduates}

Implementation of madrasa education in it formulates goals to be achieved. According to Mastuhu (2 007 : 69) strategies are formulated to achieve educational goals that are easy to understand, follow, and develop by officers according to their respective positions and roles and responsibilities. In this case, the achievements of the learning management at MDTA in the Cicantaya $n$, Caringin and Cisaat sub- districts, include the 
flourishing of Madra sah Diniyah Takmiliyah Awaliyah, Madrasah as the most important part of the compulsory basic education program in that area. From the madrasa, there are graduates who can be relied on by the community to write Arabic letters, the ability to read Arabic letters and the ability to memorize short hadiths and juz 30 in the Qur'an. Khla k character MDTA students who are polite, can help their parents, have good manners, are honest and trustworthy. In addition, the graduates can apply their MDTA Religious Knowledge MDTAd nature of Religious Knowledge Learning as Qur; an, Hadith, Figh, Aqeedah, Akhlaq, Arabic, and Tar Ikh Islam.

Based on the results of data collection through interviews and documentation studies, it was found that the competence of MDTA graduates in the implementation strategy of quality education policies and programs at MDTA was carried out by the Head of the Sub-District through the Caringin, Cicantayan and Social Welfare Districts, Cisaat District, Sukabumi Regency and the Head of the Office of Religious Affairs, Caringin, Cicantayan and District Districts. Cisaat Sukabumi, So that MDTA Graduates Have: (1) Ability MDTA students or students are able to master religious knowledge and are able to read and write Arabic letters as well as being able to perform worship according to the terms and conditions. (2) The character of MDTA students in their daily life and socializing each other and respecting their parents and always friendly and polite in their daily life. (3) Students apply religious knowledge in daily life with good manners and noble morals. (4) The characteristics of achieving quality MDTA graduates are always practicing worship and being obedient to their parents.

\section{Inhibiting factors in the application of learning management in improving the quality of MDTA graduates}

\section{MDTA Educators and Education Personnel}

One of the most important components of education is the teaching force or teacher. The success of teaching and improving the quality of education is largely determined by the condition of the teacher, therefore attention to teachers must be prioritized. In fact, the current condition of Madrasah Diniyah Takmiliyah teachers is still far from perfect, both in terms of quality and quantity. This is because teachers or educators at Madrasah Diniyah Takmiliyah are still centralized to leadership figures. This means that the main teacher at Madrasah Diniyah Takmiliyah is the leader of Madrasah Diniyah Takmiliyah, so that the provision of subject matter is very dependent on the ability of the leadership of Madrasah Diniyah Takmiliyah itself .

\section{Education Budget}

The small amount of the educational donation from the guardian of the pupil is used to pay for teaching salaries, maintenance of learning facilities, and the procurement of books to support teaching and learning activities. Although, it seems that the implementation of the learning activities is still simple and the cost of education is cheap, the results can be proud of in the community. Because at the Madrasah Diniyah level there is also a competition for students to show their talents and abilities while studying at Madrasah Diniyah. Education funds that come from the Islamic dues of the parents of students are sometimes a weakness at Madrasah Diniyah Takmilyah Awaliyah Madrasah Diniyah as a non-formal educational institution, the problem of funding becomes an obstacle in the learning process, because the funds obtained from the Islamic dues of the parents of students are considered quite light. Where the funds when managed for teaching and learning activities are deficient, so that it is not optimal in implementing learning. In addition, the role of parents or the community in implementing the payment of Islamic dues sometimes forgets, so that the income of education funds has decreased

\section{Infrastructure}

The teaching and learning process will run smoothly if it is supported by complete facilities. Because the problem of facilities is an essential problem in education, in the process of improving the quality of education, it 
is necessary to simultaneously start from the Madrasah Diniyah Takmiliyah building to the dominant problem, namely teaching aids as explanations in delivering education. The difficulty in providing educational facilities at Madrasah Diniyah Takmiliyah is also due to the lack of financial resources available at Madrasah Diniyah Takmiliyah, which also impacts on the quality of education. Many Madrasah Diniyah Takmiliyah still have limited facilities and facilities, because indeed most of the development financing is purely self-help or independent funds led by Madrasah Diniyah Takmiliyah and their families .

\section{Curriculum}

There are several things that are the root of the problem in learning management. First, the Madrasah Diniyah Takmiliyah curriculum has not been standardized nationally. Second, the Madrasah Diniyah Takmiliyah curriculum is still centralized to the leadership of Madrasah Diniyah Takmiliyah. This means that the source of the curriculum is still with the leadership of Madrasah Diniyah Takmiliyah. Third, the curriculum is too full and dense. Fourth, there is no relevance of the Madrasah Diniyah Takmiliyah curriculum with the share of the job market

Based on the research findings, it shows that the application of learning management in improving the quality of MDTA graduates in Sukabumi District faces several problems, there are about 5 problems faced by Madrasah Diniyah Takmiliyah in Sukabumi District, including: (1) The organizational structure of Madrasah Diniyah is not yet uniform; Organizational culture and society that have not been oriented towards the importance of quality education at Madrasah Diniyah Takmiliyah; ( 2 ) Limited quality of human resources and quantity of Madrasah Diniyah Takmiliyah teachers; ( 3 ) Inadequate and limited quality and quantity of facilities and infrastructure for Madrasah Diniyah Takmiliyah; ( 4 ) The curriculum standard is not yet available, the curriculum is still centralized, and the curriculum is too full and dense; There is no concept of quality education management that is used as a reference; Management of madrasah is still traditional . Institutional ownership is mostly still controlled by families; ( 5 ) Limited management financing capacity; There is still a lack of support and community participation in Madrasah Diniyah Takmiliyah; and Limited local government assistance.

The existence of Madrasah Diniyah is actually strongly protected by the National Education System Law No. 20 of 2003 which was operationalized by PP No. 55 of 2007. This means that from the aspect of quality assurance, it should have been anticipated from an early age. However, the reality in the field of some of the factors above turns out to be a real obstacle to the progress of Madrasah diniyah takmiliyah education.

\section{Demands and Expectations on the Application of Learning Management in Quality Improvement of MDT Graduates A}

The enactment of Law no. 20 of 2003 concerning the National Education System, PP. 19 of 2005 concerning National Education Standards, and in particular the promulgation of PP. 55 of 2007 concerning Religious Education and Religious Education, is both an advantage and a challenge that must be faced by education managers at Madrasah Diniyah. One of the efforts that need to be made by the management of Madrasah Diniyah Takmiliyah is as done in Sukabumi Regency with the issuance of policy regulations in the form of Regional Regulations and Regent Regulations that place Madrasah Diniyah Takmiliyah education as part of the compulsory basic education program. In this way, the existence of Madrasah Diniyah Takmiliyah education is getting stronger.

Demands and expectations on the application of learning management in improving the quality of MDTA graduates. The implementation of learning management can be carried out by the Dinyah Takmiliyah Communication Forum (FKDT) through teacher training in the form of professional teacher training or ustadz which must be carried out regularly with an adequate budget pattern. Then the demand for the formation of the Diniyah Takmiliyah Subject Teacher Conference (MGMP) so as to form a curriculum standard that is shared, the existence of appropriate and directed learning patterns and the realization of a communication forum for all MDTA teachers in the development of learning management at MDTA. In addition, demands for 
community involvement in the development of Madrasah Dinyah Talkmiliyah Awaliyah which have a modern and innovative perspective.

Based on the results of this study, improving quality education at Madrasah Diniyah Takmiliyah can be done by: a) Placing diniyah education as part of the compulsory basic education program through the issuance of policy regulations by both central and regional governments; b ) Establishing a standard curriculum standard which is the reference for the implementation of teaching and learning; $c$ ) Accredited Madrasah Diniyah; d) The existence of a person in charge of the Madrasah Diniyah quality improvement program between the Education Office and the Ministry of Religion; and e) Coordinating the organization with related parties such as the MUI, the Board of Education, Madrasah Work Deliberations, and others.

\section{Solutions and Improvements in the Future of Learning Management in Improving the Quality of MDTA Graduates}

The education level of Madrasah Diniyah which will apply should still have to pay attention to three main pillars, namely: First, the pillars of Philosophical. It is a pillar that must be used as a foundation that madrasah diniyah are fardhu ain to be maintained as a tafaqquh fiddiin educational institution through learning resources in yellow books which are the ideas, ideals and knots of the greatness of the Islamic boarding school. Second, the sociological pillar. It is a pillar on which the premise is that madrasah diniyah are not in a vacuum space, but are part of a wider social system to provide educational services in accordance with the needs and demands of society. This pillar requires in-depth reflection so that the existence of madrasah diniyah is not merely a supplement, but is expected to be the primary choice of society. Third, the juridical pillar. It is a pillar that must receive attention that education in Indonesia applies the national education system. This means that any type, form and level of education must comply with the education regulations set forth in the laws on education. PP 55/2007 is clearly one of the juridical footholds that regulate the position and existence of madrasah diniyah, diniyah education and pondok pesantren .

Various efforts have been made by the Ministry of Religion and the Regional Government in advancing and improving the quality of Madrasah Diniyah Takmiliyah, both in terms of weaknesses in Human Resources (HR) and the curriculum, many have been made, the image of Madrasah Diniyah Takmiliyah as a second-class educational institution has no longer found justification. since the implementation of Law no. 2 of 1989 concerning the National Education system, later confirmed by Law no. 20 of 2003 and the issuance of PP Number 55 of 2007 concerning Religious Education and Religious Education, but more than a solid recognition that Madrasah Diniyah Takmiliyah is part of the National Education system even though its management is under the auspices of the Ministry of Religion

From the results of research that do beb er ap A efforts in overcoming pemasalahan management implementation pembelajarn quality in MDTA form of implementation of the implementation of the regulation on religious education through the organization of Accreditation MDTA that the results be used as the data for the local government in mapping the provision of operational funding for each of each institution MDTA. Then the Strengthening of the Diniyah Takmiliyah Communication Forum (FKDT) as a forum for the MDTA organization to propose various needs in the delivery of MDTA education to both the Ministry of Religion and the Regional Government of Sukabumi Regency.

\section{The Impact of Activity Results on the Religious Life of MDTA Students}

The essence of the function of Madrasah Diniyah in general is 3 (three), namely first, as a medium for conveying religious knowledge (transfer of Islamic knowledge); second, as a medium for maintaining Islamic traditions (maintenance of Islamic Tradition); third, as a medium for printing ulama (reproduction of ulama ). This is the function of Madrasah Diniyah that is used by modern Islamic schools today which are seen by the community as an elite Muslim school. The community has this view because the community sees several differences in the implementation of these Islamic-based schools, both formal and non-formal. 
Madrasah Diniyah Takmiliyah Awaliyah functions to maintain the morality of the younger generation, as an educational institution in society, among others, as a function of socialization. Madrasah Diniyah tries to understand to students how to understand and practice moral values that live in society, religious values and national cultural values. Then a second function, namely schooling ( schooling), Madrasah Diniyah duty to provide a stock of knowledge, especially in the fields of religion, so that learners are later have certain competencies that are useful as a provision for later life. Then the function of Madrasah Diniyah as education (education) to create an elite group of educated and berahlaqul karimah to be able to contribute in maintaining the character younger generation so that negative things like $p$ erkelahian between learners , drugs and problems $d$ ekadensi morals among the people of Sukabumi can be spared .

The impact of learning management activities on improving the quality of MDTA graduates in Cicantaya, Caringin, and Cisaat Districts can be seen from the dominance of religious community life, MDTA graduates have succeeded in shaping themselves to become religious leaders and community leaders, and diniyah education has an impact on reducing the moral decadence of generations. young people in Sukabumi Regency.

\section{CONCLUSIONS}

In general, the Implementation of Learning Management in Improving the Quality of Madrasah Diniyah Takmiliyah Awaliyah (MDTA) Graduates in Cicantayan, Caringin and Cisaat Districts, Sukabumi Regency has not run optimally.

The product of Sukabumi Regency Government Policy in the Implementation of Learning Management in Improving the Quality of MDTA Graduates in Caringin District, Cicantayan, Cisaat District, Sukabumi Regency has been successfully implemented even though in the realization of the operational assistance budget and the pattern of guidance and supervision is still not optimal . Meanwhile, the achievement of Learning Management on the competence of student graduates, both in the realm of attitudes, knowledge and skills, is sufficient to meet the competency standards of graduates. Even so, the learning pattern carried out still does not meet the proper learning process standards.

Meanwhile, the demands and hopes are in the form of teacher professional or religious teacher should be routine with the pattern of an adequate budget. Then the demand for the formation of the Diniyah Takmiliyah Subject Teacher Conference (MGMP) so as to form a curriculum standard that is shared, the existence of appropriate and directed learning patterns and the realization of a communication forum for all MDTA teachers in the development of learning management at MDTA. In addition, demands for community involvement in the development of Madrasah Dinyah Talkmiliyah Awaliyah which have a modern and innovative perspective

The results of this study recommend especially to the Regional Government of Sukabumi district, in making regulations on religious and regional religious education, consistency and continuity should be followed, programmed, directed and measured and can help optimally in coaching, completing various facilities needed by schools such as adding new classrooms RKS), libraries, and reference books for teachers and students as well as improving and expediting learning activities.

\section{REFERENCES}

Abdul Wahab, Solichin.(20040 .Analisis Kebijaksanaan dari Formulasi ke Implementasi Kebijakan Negara, Jakarta : Bumi Aksara. 
Creswell, J.W. (2017). Research Design (Pendekatan Kualitatif, Kuantitatif, Dan Campuran). Edisi Ke: 4. Cetakan Ke: 2. Diterjemahkan Oleh: Achmad Fawaid Dan Rianayati Kusmini Pancasari. Yogyakarta : Pustaka Pelajar.

Departemen Agama RI (2009) Pedoman Penyelenggaraan Diniyah Takmiliyah, Jakarta: Direktorat Pendidikan Diniyah dan Pondok Pesantren, Dirjen Pendidikan Islam

Hidarya, I., Mudrikah, A., \& Sauri, R. (2020). Implementation of Regulation of The Minister of Religion Number 2 of 2012 for Islamic Education Supervisers at Schools in The Department of Education in Sukabumi Regency. International Journal of Nusantara Islam, 8(2), 226-239. doi:https://doi.org/10.15575/ijni.v8i2.11082

Ilyas, I. (2016). Pendidikan Karakter Melalui Homeschooling. Journal of Nonformal Education, 2(1).

Keputusan Bupati Sukabumi Nomor 451.05/Kep.255.SK/2018 tentang Tim Koordinasi Wajib Belajar Pendidikan Keagamaan Islam.

Keputusan Kepala Kantor Kementerian Agama Kabupaten Sukabumi Nomor 6283 Tahun 2018 tentang Standar Pelayanan Minimal Pendidikan Diniyah Nonformal Tingkat Awaliyah pada Kantor Kemeterian Agama Kabupaten Sukabumi.

Kompri, M. P. I. (2018). Manajemen \& Kepemimpinan Pondok Pesantren. Prenada Media.

Mastuhu. 2007. Dinamika sistem pendidikan pesantren. Jakarta: Lentera Hati.

Moleong, L.J. (2007). Metodologi Penelitian Kualitatif (Edisi Revisi). Cetakan Ke: 24. Bandung: Pt. Remaja Rosdakarya.

Peraturan Daerah Kabupaten Sukabumi Nomor 8 Tahun 2009 Tentang wajib Belajar Pendidikan Keagamaan Islam

Peraturan Menteri Agama Republik Indonesia. Nomor 13 Tahun 2014 Tentang. Pendidikan Keagamaan Islam.

Peraturan Pemerintah Republik Indonesia Nomor 19 Tahun 2005 Tentang Standar Nasional Pendidikan.

Peraturan Pemerintah Republik Indonesia Nomor 55 Tahun 2007 Tentang Pendidikan Agama Dan Pendidikan Keagamaan.

Saepudin, J. (2018). Integrasi pembelajaran madrasah diniyah takmiliyah ke sekolah (studi kasus di Sekolah Dasar Negeri Cisaat Kabupaten Sukabumi). Jurnal SMART (Studi Masyarakat, Religi, dan Tradisi), 4(2), 231-246. DOI: https://doi.org/10.18784/smart.v4i2.667

Undang-Undang Republik Indonesia Nomor 20 Tahun 2003 Tentang Sistem Pendidikan Nasional.

Wandini, R. R. (2018). Games Pak Pos Membawa Surat Pada Sintax Model Pembelajaran Tematik. Jurnal Raudhah, 6(1). DOI: http://dx.doi.org/10.30829/raudhah.v6i1.268.

Winda, W., Kurnianto, R., \& Ariyanto, A. (2018). Manajemen Pembelajaran Madrasah Diniyah Nurul Huda Krajan Krebet Jambon Ponorogo. TARBAWl: Journal on Islamic Education, 2(2), 26-39. DOI: 10.24269/tarbawi.v2i2.176 
Learning Management in Improving the Quality of Graduates Madrasah Diniyah Takmiliyah Awaliyah (MDTA) in Sukabumi District

Zamroji, M. (2020). Quo Vadis Implementasi Model Pengembangan Mutu Juran Di Lembaga Pendidikan Islam. Jurnal Ats-Tsaqofi, 2(1), 8-22. 